\title{
Traumer og ånder efter krig i Uganda Konfigurationer af vold og behandling
}

\section{Lars Hedegaard Williams \& Lotte Meinert}

Aarhus Universitet

lhw@cas.au.dk

lotte.meinert@cas.au.dk

Williams, Lars Hedegaard; Meinert, Lotte (2017). 'Traumer og ånder efter krig i Uganda: Konfigurationer af vold og behandling', Tidsskrift for Forskning i Sygdom og Samfund, nr. 26, 63-88

I kølvandet på 20 års borgerkrig $i$ det nordlige Uganda fulgte en bølge af traumer, onde ånder og vold, som fortsat forpester livet og fordrer handling. Brutaliteten og de mange ubegravede lig som krigen efterlod, opleves af mange som årsag til forskellige former for åndelig og social kontaminering. I en biomedicinsk forståelse beskrives forstyrrelserne som Post Traumatisk Stress Syndrom (PTSD), hos de traditionelle behandlere (ajwaki) kaldes fxnomenerne cen, og i kirkerne betragtes problemerne som djævlens værk. Der er bred enighed mellem de forskellige tilgange om, at noget er galt, og folk lider herunder, men de varierende begrebsliggørelser af problemerne peger mod forskellige handlemuligheder. Igennem en fyldig skildring af en enkelt case analyserer vi disse problemer og behandlingsformer med begreber om social smitte, kontaminering, og konfigurationer. Vi argumenterer med begrebet konfiguration for, at problemer med traumer og ånder både konstitueres af krigens vold og de forskelligartede, men begrænsede behandlingsmuligheder, som er tilgængelig i det nordlige Uganda i dag. 
Trauma and spirits after war in Uganda: Configurations of violence and treatment

In the aftermath of 20 years of civil war in northern Uganda lives in the Acholi-region are still polluted by trauma, evil spirits and violence. The brutality and the many unburied bodies left behind by the war are experienced by many as the reason for a variety of forms of social and spiritual pollution. These maladies are understood as PTSD in biomedical terms, as the spirit possession cen by local, traditional healers and as the work of the devil within the many churches. There is a broader agreement between these different positions that something is wrong and that families and individuals are suffering, but the variety of conceptualizations of the problems point towards different paths of action. In presenting an analysis of these problems and forms of treatment, by applying the concepts of social contagion, contamination and configurations. We argue with the concept of configuration, that problems with trauma and spirits are constituted both by the violence of the war and the various, but limited treatment options that are available in northern Uganda today.

\section{Alfreds bror}

I en lerhytte i det nordlige Uganda skændes to halvbrødre. Det er en torsdag aften i 1997. Mørket er ved at lægge sig over lejren for internt fordrevne, hvor skumringen aftegner lerhytternes græstage mod himlen. De to brødre er oprevede. De er unge, brede mænd, hærdede og stærke af markarbejde siden de som børn arbejdede sammen på familiens jord. Den ældste bror James er vred på regeringen og den måde, hvorpå de behandler folk fra Acholi-regionen. Han er parat til oprør, han vil slutte sig til rebellerne fra Lord's Resistance Army i bushen, og han ønsker, at den yngre halvbror Alfred skal drage med ham, så de sammen kan løfte våben mod regeringen. Men Alfred vil ikke med. Han mener ikke, at volden kan føre noget godt med sig.

Den ældre bror James tilslutter sig rebelgruppen samme aften, men to dage senere bliver han skudt af regeringstropperne. Alfred og deres far tager ud for at hente James' lig. De leder efter hans krop blandt hundredevis af døde efterladt på en mark nord for lejren i Awach.

To år efter broderens død begynder Alfred at blive syg. Det begynder om natten, hvor han fornemmer, at der er noget i hans værelse, og om morgenen er Alfred anderledes. Det føles som en kulde, der kryber ind under huden på ham eller dækker hans krop. Som om noget udefra tager bolig i ham. Han truer og råber af folk. Han bliver aggressiv og voldsom over for familiemedlemmer og venner. Han stopper med at spise og drikke i perioder og begynder at vandre hvileløst 
rundt $\mathrm{i}$ landsbyen, og han kan ofte ikke kende sine familiemedlemmer. Hans mor Beatrice fortæller, at han en tidlig morgen kommer ind i huset til forældrene og begynder at le højt uden nogen grund. Også hans lillesøster, som dengang kun var omkring 6 år, husker, da Alfred begyndte at råbe op om natten og te sig, så brødrene måtte holde ham. Alfred begynder at se syner, hvor mænd bevæbnede med macheter og geværer kommer efter ham. Han drømmer også om sin døde bror i bushen, fortæller hans mor. Han er blevet det, som man på lokalsproget acholi kalder apoya, nemlig gal, og i perioder er det så slemt at familien må binde ham inde i hytten.

\section{LRA krigen og dens eftervirkninger}

To generationer har i det nordlige Uganda gennemlevet brutale krige og kontrolleret internering i Lejre for Internt Fordrevne (IDP camps). Både rebelgruppen Lord's Resistance Army (LRA), som kæmpede mod regeringen, og det ugandiske militær (UPDF) udførte den ene massakre efter den anden på befolkningen i perioden mellem 1986 og 2006. I 1990'erne satte regeringen befolkningen i IDP camps for at 'beskytte dem' mod rebellerne. Her udførte militæret imidlertid også overgreb på befolkningen, og tiden i lejrene er blevet beskrevet som en form for 'social tortur', fordi de almene konsekvenser af tortur hos individer - svækkelse, afhængighed, frygt og desorientering (Suedfeld, 1990) - kunne tilskrives en hel befolkning (Dolan, 2008). Titusinder af børn og unge blev taget som børnesoldater af rebelgruppen, hvor de oplevede former for vold og overgreb, som i brutalitet overgår, hvad de fleste kan forestille sig. I godt 20 år har oplevelser med ekstrem vold, svigt og mistillid således struktureret relationerne mellem mennesker, mellem familiemedlemmer og naboer (Meinert 2015). Et blik på regionens historie set igennem voldens linse kunne begynde meget tidligere med arabernes slavehandel i området og med kolonitiden under det britiske styre (Atkinson, 1994). Voldens arv trækker lange tråde tilbage i flere generationer, men for de fleste er det den sidste krig, som fylder mest i bevidstheden. Med præsident Musevenis magtovertagelse i 1986 kom dannelsen af de første rebelgrupper i regionen, som var i opposition til regeringen, hvoraf de meste kendte er Alice Lakwenas Holy Spirit Movement i 1980'erne efterfulgt af LRA, ledet af Joseph Kony. LRA blev særligt kendt for sin brug af børnesoldater, efter den amerikanske organisation Invisible Children lancerede aktivismevideoen Kony2012, der blev set over 100 millioner gange på YouTube inden for den første uge, selvom krigen på det tidspunkt var ovre. 
Efter fredsforhandlingerne har området været stabilt, og folk genopbygger fortsat deres liv med hinanden. Men nye problemer er opstået i efterdønningerne af krigen og volden. Alkoholisme, vold i familier, konflikter om land, psykiske lidelser og fysiske handicap er aktuelle problemer, som mange berøres af. De mange år med vold og krig har skabt en arv, som bliver ved med at påvirke og kontaminere livet, fordi volden transformeres til nye problemer og tager nye former (Meinert \& Whyte, 2016b). Mange nye aktører og organisationer har fundet en plads i efterkrigstidens virvar med bud på at behandle, beskrive og forklare problemerne. De store katolske og protestantiske kirker med deres mangeårige indflydelse, de nyere pinsekirker med eksorcisme og bønsfællesskaber, de traditionelle behandlere og urtekyndige, sygehusene med læger og biomedicin og humanitære organisationer med udviklingsprogrammer og traumebehandlinger er nogle af de institutioner, som byder ind med forklaringsmodeller og behandlingsveje. Det vil imidlertid være misvisende at beskrive situationen som et velorganiseret pluralistisk 'imperium' af behandlingsmuligheder, der byder sig til (ibid). Folk med problemer og deres familier må aktivt opsøge og selv skaffe midler til at afprøve forskellige terapeutiske veje for at finde lindring, og der er ofte blindgyder, loops, store omkostninger og frustrationer på vejen.

Når eftervirkningerne af vold sættes på begreb som Post Traumatisk Stress Disorder (PTSD), som åndebesættelse eller noget tredje, får de en særlig form, som peger i retning af bestemte handlemuligheder. Man kunne hævde, som Fassin og Rechtman (2007), at de institutioner, som tilbyder terapi, skaber imperier af behandling, der er årsag til, at begreber som traumer spredes. Vi finder det imidlertid centralt at bibeholde et fokus på, at det er krigens vold og dens transformationer, der har spredt sig og skabt smittevejene for forskellige problemer i det nordlige Uganda. Voldens eftervirkninger har bragt nye praksisser, såsom psykoterapi, med sig fra fjerne egne, men dette er sekundært. Der er også ældre og kontinuerlige praksisser, såsom traditionelle healere, der længe har behandlet fænomener, der minder meget om traumer. Forskere som Fassin \& Recthman (2007) understreger den sociale konstruktion af, hvordan diagnostiske begreber spreder sig som et imperium og understreger de nye sprog for lidelse, som spredes fra det Globale Nord ${ }^{1}$. Vi ønsker at bringe flere processer end de sociale konstruktioner i fokus i vores undersøgelse af, hvordan problemerne konfigureres. Når eksempelvis PTSD skabes som kategori i nye kontekster og bliver populær, er det ikke kun, fordi institutioner tilbyder behandling. Det er også, fordi mennesker oplever problematiske fænomener i et omfang, der kalder på handling og lindring. Dette fænomenologiske niveau af erfaring og sansning af vold og dens eftervirkninger 
og udbredelse er en vigtig del af de konfigurationer, som vi beskriver. Herudover stiller vi skarpt på konkrete praksisser og betydningen af materialitet og tilgængelighed af medicin eller andre ressourcer i konfigurationer af, hvordan traumer og ånder spreder sig i det nordlige Uganda.

Vi tager derfor udgangspunkt i erfaringen af volden; Alfreds møde med de mange døde kroppe og håndteringen af brorens lig, fordi volden er det primære fænomen, som kommer til at skabe den lidelse, som følger Alfred og familien. Volden er smittevejen for en række problemer. Vores ærinde er at vise det processuelle, transformative og uafsluttede, som vold bringer med sig, fordi eftervirkningerne af volden siver ud i hverdagen som nye typer af problemer og hele tiden transformeres til nye former. Dette fænomenologiske niveau står imidlertid ikke alene. Vi fortsætter herfra sammen med Alfred og hans familie ind i de institutioner, som sætter volden og dens eftervirkninger på begreb og tilbyder behandlinger. Disse institutioner er med til at konstituere problemerne symbolsk og i det sproglige, hvormed de også udmøntes og spredes som fænomener. Institutionernes opkomst, praksisser, tilgængeligheden af medicin og ressourcer spiller afgørende ind i konfigurationerne.

\section{Social smitte, kontaminering og konfigurationer som analytiske begreber}

De fænomenologiske, praksisorienterede og materielle perspektiver er således vigtige delelementer i de systemiske konfigurationer, hvor problemer med traumer og ånder bliver til. Vi gør brug af medicin-historikeren Rosenbergs (1992) begreber social smitte, kontaminering og konfigurationer som analytiske perspektiver til at beskrive og nærme os en forståelse af disse systemiske processer.

I vores brug af begreberne refererer social smitte til, når noget overføres fra en aktør til en anden, ofte i bio-sociale processer. Kontaminering henviser til processer, hvor aktører pådrager sig noget fra omgivelserne eller miljøet. Kontaminering som begreb adskiller sig fra forurening, idet det ikke antages, at noget var 'rent', før det blev kontamineret. Konfigurationer er det samspil af forskellige former for social smitte og kontaminering, samt andre bio-sociale og materielle processer, som forekommer over tid. Konfigurationer er dynamiske, således at problemer og diagnoser forandrer sig løbende alt afhængig af hvilke fænomener, aktører, institutioner, praksisser og genstande, som er involveret. Begreberne bidrager således 
med et materielt fokus, hvor ikke kun sprog og symboler, men også konkrete materialer og ressourcer som piller, recepter, bibler, kalabash'er samt bygninger som sygehuse, behandlings-hytter hos traditionelle behandlere og kirker er med til at konstituere og mediere lidelsen på bestemte tidspunkter. Vi håber, at begreberne kan assistere til at bibeholde en kompleksitet i forståelsen af enkelte forløb ved ikke at fastlåse én konstellation af symptomer til én endelig forklaringsmodel, men at de derimod kan vise, at varierende konfigurationer på forskellige tidspunkter udgør det samlede sygdomsbillede, som så igen over tid ændrer sig og indgår i nye konfigurationer. Et sådant perspektiv kalder også på en særlig pragmatisk epistemologi (mere herom i sidste afsnit).

I Alfreds tilfælde tager lidelsen hele tiden nye former afhængigt af tilstedevær og fravær af psykofarmaka, penge og andre ressourcer, ideer om sygdom, arbejde, vold, druk, og hvordan disse eksisterer inden for konfigurationer af fællesskaber såsom kirkefællesskabet, drukkammerater i byen eller indlogering hos en ajwaka healer. Ved at følge Alberts forløb igennem de forskellige systemer kan vi placere og forstå cen og traumer i systemiske konfigurationer sammen med vold, ressourcer, familier, behandlingsinstitutioner og -aktører og som medskaber af andre lidelser. Vi undgår derved at betragte problemet som entiteter 'inde i' individer og i kausale co-morbiditets forhold. Via disse konfigurationer kan vi følge problemer over tid, og se i hvilke systemiske sammenhænge lidelserne kommer frem, forsvinder, 'svulmer op' eller formindskes.

\section{Feltarbejde}

Materialet, som denne artikel bygger på, er baseret på antropologisk feltarbejde i regionen fra 2014-16. Vi har valgt Alfreds case som gennemgående i denne artikel, fordi den både illustrerer: (1) den pluralisme af behandlingsmuligheder og -systemer, som findes i det nordlige Uganda, (2) den pragmatisme, hvormed mennesker her tilgår dagliglivets sygdomsproblemer, hvor handling og lindring synes at være centrale fremfor endegyldige forklaringer og kategoriseringer af problemernes sammenhæng og ophav. Endelig har Alfreds case givet anledning til vores centrale argument, nemlig at (3) de systemiske konfigurationer, som bestemte mennesker indgår i og søger rundt i for at finde løsninger på problemer, er med til at give forskellige udtryk og konstituere problemerne.

Vi kom til at kende Alfred og hans familie fra forskellige positioner. Lotte mødte først Alfreds mor, Beatrice, i 2014 i forbindelse med et studie af traumer og ån- 
der udført i samarbejde med Susan Reynolds Whyte, som omfattede 19 familier, to sundhedsklinikker, interviews med traditionelle behandlere, NGO'er og præster. Alfreds mor fortalte om familiens og sønnens lidelser fra sit perspektiv som forælder. Senere mødte Lotte Alfreds søster, der berettede om Alfred fra sit perspektiv, og endelig interviewede Lotte Alfred og fulgte hans proces i 2015.

Lars boede hos Alfreds familie i begyndelsen af 2016 som et led i sit PhD feltarbejde om ånder og traumer. Alfreds familie var den første acholi familie, som Lars boede hos i landsbyen Awach, og det var med udgangspunkt i deres familie, at Lars begyndte sit studie af dagliglivet i Acholi, af sproget og af religiøse og behandlingssøgende praksisser. Lars har således levet en dagligdag sammen med Alfred og hans familie og over en periode deltaget $i$ familiens daglige gøremål. Alfred og hans familie har været en central case i de etnografiske studier, vi begge har foretaget i det nordlige Uganda over en årrække.

Vi har valgt at præsentere en enkelt udvidet case over en årrække udfra den udvidede case metode (Burawoy, 1998; 2009, Gluckman 2012), fordi vi herved kan præsentere nuancer og detaljer på en langt mere grundig måde end med flere cases. Vi lægger os herved op ad den erfaringsnære tradition i antropologien og medicinsk antropologi, hvor enkelte informanter eller familier spiller en central rolle (Abu-Loghod 1991; Shostak, 2014; Mattingly, 2014; Good 1993; Desjarlais, 1996).

\section{Alfreds lidelse og behandlingsveje}

\section{Hospitalet og biomedicinering}

Da Alfreds lidelse bliver mere alvorlig indlægger familien ham på et hospital i den nærliggende by Gulu. Her får han piller og injektioner med sløvende medicin. Da vi møder Alfred, kan han ikke huske, hvilken medikamenter han fik udover chlorpromazine, men det mest almindelige medicin i området ved tilfælde af apoya er at give en kombination af valparin og chlorpromazine i pilleform, som virker sløvende, samt injektioner med fluphenazine ved psykoselignende adfærd og amitriptylin ved depressionslignende adfærd. På Gulu Referral Hospital, som har en nyligt åbnet klinik for psykisk sygdom, deles den psykopatologiske diagnostik overvejende i to kategorier: major or minor mental illness. Under 'major mental illness' findes bipolare lidelser, skizofreni og psykoser. Under 'minor mental illness' klassificeres PTSD, fobier, anoreksi, bulimi og generelle angstlidelser. 
Alfred er indlagt i fire måneder på hospitalet. Under sit ophold spiser eller drikker han nærmest ikke. I lange perioder drikker han kun lidt mælk hver dag, fortæller han. Medicinen gør ham sløv, og han sover meget af tiden. Men ofte er han også aggressiv og generer sine medpatienter og de ansatte, hvilket resulterer i øget medicinering. Hans far hjælper med at passe ham på hospitalet, men i en periode, hvor bedstemoren er syg i landsbyen, er faren meget væk. I denne periode forværres Alfreds symptomer. Flere gange forsøger han at flygte fra hospitalet, uden at han kan huske det efterfølgende. Personalet ender med at binde ham til sengen.

Alfreds bror, Bennet, fortæller at lægerne sagde, Alfred led under tam ma dwong, han 'over-tænker'; er ekstremt bekymret og stresset. Dette kan ifølge lægerne medføre wiye obale, at han mister sine sanser og sin hukommelse, fortæller Bennet. Men Bennet er skeptisk overfor den diagnose. Han mener ikke, at Alfred har haft grund til at 'over-tænke', særligt fordi han på det tidspunkt ikke selv havde stiftet familie. Bennet mener ikke, at Alfreds 'over-tænkning' kan skyldes broderens død.

“James var ikke kun Alfreds bror. Han tilhørte os alle. Jeg og de andre søskende har tænkt meget på James efter hans død. Jeg ser stadig hans ansigt for mig. Men vi er ikke blevet gale. Og det skete jo heller ikke kun i vores familie. Der er så mange familier i landsbyen, som har mistede nogen i krigen, men det har ikke skabt gale i alle hjem".

Ifølge Bennet må grunden til Alfreds lidelse findes andetsteds og i andre typer af forklaringer. Bennet nævner ikke, at Alfred var i kontakt med brorens lig og så de mange døde kroppe. Han mener derimod, at nogen kunne have forhekset Alfred. Det er meget almindeligt, forklarer Bennet, hvis nogen er misundelig. Alfred var meget dygtig i skolen, og det vækker ofte folks jalousi, hvilket kunne have fået nogen til at bruge hekseri til at kaste en forbandelse over Alfred. Beatrice, Alfreds mor, peger også mod dette som en mulig medvirkende forklaring.

Flere informanter fra området nævner, at handlinger, som viser offentlig empati, kan gøre én sårbar overfor for åndelig kontaminering. En ung mand fortalte om tiden i bushen med rebellerne, hvor der var én, som åbenlyst viste sympati med ofrene for rebellernes handlinger ved, at han lagde hånden på hjertet (se Meinert \& Whyte, 2016b). En sådan handling kan 'åbne en op' for at pådrage sig en åndelig kontaminering (se også Hopwood \& Osburm, 2008), hvilket også peger på idéen om et 'porøst selv'. Ved at undgå at vise empati og gøre sig hård udvikler man en type immunitet overfor åndelige påvirkninger. Så måske har Alberts tætte emotionelle bånd og mulige åbne empati med den døde halvbror 'åbnet ham op' for en åndelig kontaminering. Faren, som også var med til at hente liget, havde 
muligvis 'gjort sig hård', så han var immun, men det melder beretningerne ikke videre om, og faren er nu død. Broderen Bennet og andre familiemedlemmer er også åbne for andre mulige forklaringer, og de nøjes med at referere til Alberts lidelse som 'det' eller 'disse ting', fordi de ikke er sikre på en forklarende terminologi, men forholder sig spørgende til fænomenet.

\section{I dialog med ånderne}

Efter Alfred udskrives fra hospitalet, vender han hjem til sin familie i landsbyen. Han er ikke rask, men lægerne siger, at de ikke kan gøre mere. Han får stadig medicin, men familien har i det lange løb ikke råd til den dyre psykofarmaka, og de synes ikke, at medicinen virker godt nok. Alfreds mor tager sig af sin syge søn i denne periode og bliver assisteret af en lumi yat kwaro, som har forstand på urtemedicin. I starten skulle Beatrice tage turen ind til Gulu by for at få fat på de dulmende urter, men med tiden lærer hun selv at identificere planterne og kan gå i bushen og finde dem. Urterne synes at have en 'kølende' effekt på Alfreds symptomer, men han bliver ikke rask.

Efter noget tid er Alfreds mor, Beatrice, parat til at lede andetsteds efter lindring til sin syge søn. "Karo Woko" siger hun til familien, som betyder at "gå udenfor", hvilket er det udtryk, man på acholi bruger for at lede efter en ajwaka, en traditionel behandler. En ajwaka adskiller sig fra en lumi yat kwaro ved at kunne gå i dialog med ånderne, hvilken er en praksis, hvor man afprøver svar og ikke blot symptomlindring som ved urtebehandling (Whyte 1997). En ajwaka vil ofte også bruge urtemedicin, hvor en luni yat kwaro kun anvender urtemedicin. Familien går til flere ajwaki $(\mathrm{pl})$, som der er tradition for, inden de bestemmer sig for én, som, de mener, kan hjælpe med at finde en løsning. Alfred bliver bragt ud til hende, og han indlogeres $\mathrm{i}$ to måneder. Her får han i første omgang symptombehandlende urtemedicin. Sidenhen går behandleren i dialog med ånderne omkring, hvad de skal have som kompensation for at forlade Alfred.

I Acholi-regionen, ligesom andre steder i Uganda (se Whyte 1997, Mogensen 2002, Meinert 2008), er det almindeligt ved lidelser, hvis ophav man enten ikke kender, eller hvor familien konstaterer, at problemet har åndelig karakter, at bede en traditionel behandler om at gå i dialog med ånderne. Dette kan foregå på en lang række måder og vare kortere eller længere tid, men almindeligvis er processen således, at behandleren spørger ånderne, som har besat den lidende, hvad de kræver for at forlade vedkommende igen. En dialog går i gang, indtil en form for forklaring er etableret, og en passende ofring er fundet, og ånderne er klar til at 
forlade personen. Ajwaka'en mener, at Alfred kunne lide under en form for åndelig kontaminering kaldet cen (se næste afsnit), en lidelse som kan forurene én ved, at man for eksempel befinder sig i områder, hvor folk er blevet dræbt på umoralsk vis (Finnström, 2003). Da Alfred hentede brorens lig i området, hvor mange var blevet dræbt, er han således sandsynligvis blevet forurenet med døde menneskers cen, måske er det brorens afdøde ånd, som forfølger ham, eller måske er der noget tredje på spil.

Efter to måneder med urtebehandling og ofringer hos behandleren har Alfred det bedre. Hans symptomer er væk, og han vender hjem til sin familie. Alfreds mor havde ikke råd til at betale ajwaka'en det høje beløb, som hun krævede for behandlingen, men ved at sælge en del af familiens forråd fra marken lykkedes det at afbetale hende gradvist. Forrådet fra marken var vigtigt for familien, særligt i denne periode hvor krigen stadig rasede mellem regeringen og oprørsgruppen, fordi madrationerne, som uddeles. ikke slog til, og det var særdeles farligt og vanskeligt at udføre arbejde i marken på grund af miner og soldater som patruljerede. Alfreds søster fortæller, at besøget hos ajwaka'en endvidere skabte konflikter, fordi der var noget i behandlingen, som pegede på, at det var Alfreds stedmor, hans fars anden kone, som havde kastet hekseri på Alfred, fordi stedmorens egen søn, James, var død. Dette blev dog aldrig bekræftet og virker til at være blevet glemt igen.

Alfred begynder på en håndværkerskole, hvor han går i et år. Herefter får han arbejde inde i Gulu by som håndværker. Alfreds symptomer er væk i flere år. Inde $i$ byen begynder Alfred at drikke og ryge sammen med sine kollegaer og venner. Han får efterhånden et stort alkoholforbrug. Rygning af marijuana bliver i denne periode også udbredt blandt mange unge mænd i befolkningen både i byen Gulu og på landet.

\section{'Det' vender tilbage igen}

Nytårsaften i 2001 holder brødrene fest sammen inde i byen. De drikker, og stemningen er høj. Men i løbet af aftenen begynder Alfred at opføre sig besynderligt. Han er mere aggressiv end ellers og siger ting, som er ude af kontekst. Brødrene tror, at han har fået for meget at drikke, men den ene bror, Bennet, synes, at der er noget anderledes over hans opførsel. Han tænker, at Alfred måske er ved at blive syg igen. Med ét farer Alfred ud af huset og løber ned af gaderne og forsvinder. Brødrene leder efter ham inde i byen og finder ham endelig i en flok af mænd, som slår og sparker ham. De beder mændene om at lade Albert gå, fordi han er en syg. 
Alfred slipper væk, men næste dag kan han ikke huske episoden, og da vidste brødrene, at han nu var blevet syg igen. 'Det' var vendt tilbage.

Familien havde ikke råd til at gå tilbage til den traditionelle behandler igen, så de bragte klanen sammen for at finde en løsning. Det blev vedtaget, at familien skulle prøve kirken i denne omgang, og se om Alfred kunne blive rask ved Guds kraft. De tog ham til The Pentecostal Assembly of God (PAG), en lokal pinsekirke, hvor en ny behandlingsproces skulle gå i gang. Stephen, en af Alfreds klanbrødre, var medlem af PAG og havde oplevet kirkens processer med behandling tidligere. Han mente, at det ville være godt for Alfred, som accepterede forslaget.

\section{Kirken, bønnen og djævlen}

Pastoren for den lokale pinsekirke samlede sin menighed, for at de skulle bede for Alfred. Præsten mente, at det måtte være djævlen, som havde grebet ind i Alfreds liv. I det nordlige Uganda er forklaringer, som henviser til djævlen, anderledes end de, som henviser til ånder. Ånder er generelt mere personlige og har ofte en personlig slægtskabsrelation til den besatte, og praksisser med ånder antager en dialogisk form. Hvis det er djævlen, som er på spil, bør man ikke indgå i dialog. Hvor åndernes tilstedevær og krav ofte er retfærdige responser på en konkret begået uret, repræsenterer djævlen en mere upersonlig kraft, som griber ind i éns liv tilfældigt eller på grund af ens egne eller familiemedlemmers umoralske adfærd. Her hjælper dialog og kompensation ikke, men derimod eksorcisme (Csordas, 1997).

Inden Alfreds behandling kunne gå i gang, forklarede menigheden ham reglerne for at være en del af kirkemiljøet. Alkohol, rygning og løse relationer til det modsatte køn er forbudt. Man skal arbejde hårdt, bede mange gange dagligt og acceptere Jesus som sin personlige frelser. Mod dette får man til gengæld et broderskab, som hjælper en med dagligdagens udfordringer og støtter én i den nye livsstil og endda sommetider i økonomiske forhold. Alfred accepterede, og menigheden bedte for ham igennem flere dage og fastede på hans vegne. De holdt sig fra mad og vand i tre dage, mens de bad intenst sammen med Alfred. Efter denne indledende fase kom Alfred i kirken hver dag. Han fik tildelt små opgaver, som menigheden mente, at han kunne klare, såsom at ordne have eller reparere den nedslidte kirkebygning. Han lærte at dedikere sit daglige arbejde til Gud, tilstå sine synder og jævnligt at gå til 'samtaleterapi' (nywako tam) hos den lokale præst. Han lærte en bønspraksis, som bød ham at bede, når han stod op, inden maden, inden arbejde og inden han gik i seng om aftenen. I dag siger Alfred, at 
han er rask. 'Det' er ikke kommet tilbage, og Alfred opretholder sin tilværelse, sine familierelationer og sit helbred.

At det netop er i pinsekirken, Alfred ender med at finde et helende fællesskab skal måske i mindre grad tilskrives det specifikke kristne indhold i kirkens verdenssyn, som det muligvis kan tilskrives dét at være en del af et fællesskab, som understøtter ham, og tildeler ham opgaver efter hans formåen. Ager (1993;1997) har peget på netop fællesskabets effektivitet i genoprettelsen af menneskers liv i post-konflikt områder, hvordan konkrete fællesskaber kan fungere til at få organiseret familie- og sociale relationer på ny, og det er sandsynligvis denne proces, som Alfred har fundet helende.

Historien om Alfred er på en gang en historie om et specifikt lidelsesforløb og samtidig gældende for behandlingssøgende adfærd i det nordlige Uganda mere generelt. Historien viser den brede pallet af behandlingspraksisser, som findes i regionen. Men den peger også på noget andet, nemlig at det kan være vanskeligt at slå ned på, hvad det mere præcist er, som forårsager lidelse, og afhængigt af hvilken behandling man bruger, får man forskellige svar. Nogle forklaringer udelukker principielt andre, men i praksis afprøver folk ofte flere muligheder, og hvad årsager og virkninger er, får lov at stå lidt hen i det uvisse. Hvis man spørger Alfred selv, siger han i en pragmatisk tone, at "man kan jo blive syg af alt muligt, men nu er jeg rask igen". Han synes tydeligvis ikke om at spekulere i årsagsforklaringer, hvilket vi som feltarbejdere naturligvis accepterer, men i den videre udforskning forsøger vi at argumentere for, at der i et lidelsesforløb foregår en række former for social smitte, kontaminering og konfigurationer, som tilsammen giver det udtryk som lidelsen løbende får. Derfor hjælper det heller ikke, hvis man vil bibeholde både det fænomenologiske og praksisorienterede perspektiv, at henvise til entiteter som 'ånder' eller 'traumer' som årsagsforklaringer i sig selv. For nye situationer bringer konstant nye fortolkningsmuligheder og behandlingsveje med sig. De mange aktører og institutioner, som bliver en del af Alfreds behandlingsforløb, referer løbende og spørgende til djævlen, ånder, Alfreds 'over-tænkning', hekseri og oplevelsen af broderen James' voldelige død som årsager til Alfreds lidelse. Bidraget ved begreberne om konfiguration, social smitte og kontaminering bliver her, at vi kan komme ud over at referere til entiteter som eksempelvis 'ånder' eller 'traumer' som årsagsforklaringer og i stedet henvise til sammenhænge mellem materielle forhold, praksisser og ideer, som løbende blandes sammen på nye måder. Ved at henvise til konfigurationer af materialer, praksisser og fortolkninger kan vi i højere grad vise, hvad folk gør fra situation til situation, i stedet for at fastlåse en forklaringsmodel til en bestemt entitet som 'traume' eller 'djævlen'. 
Dette bidrager til studiet af pragmatisme i forhold til behandlingssøgende adfærd ved ikke blot at lægge vægt på oplevelser og praksisser, men konteksten for disse praksisser og hvordan denne forandres over tid. Det er altså selve transformationen af sygdomsbilledet og behandlingsautoriteternes skiftende positioner, som bringes frem i lyset (og ikke entiteter som bagvedliggende årsagsforklaringer). Hver gang Alfred træder ind i et nyt behandlingsrum, står nye aspekter og autoriteter i forgrunden, og andre træder tilbage. Nye konfigurationer skabes. I det følgende fokuserer vi på to centrale og overlappende lidelsesbegreber, som er meget udbredte på dette historiske tidspunkt i Acholi-regionen, nemlig cen og traumer. Vi præsenterer de smitteveje og behandlingsformer, som disse lidelsesbegreber fører med sig, og hvordan disse løbende blandes ind i hinanden i skiftende konfigurationer.

\section{Cen og Traumer: Behandlingspraksisser og konfigurationer}

To centrale - men ofte overlappende - begreber i forskellige behandlingspraksisser for lidelser såsom Alfreds er acholi-begrebet om cen og det globalt udbredte, psykologiske begreb om traumer. Begge disse begreber fylder en betydelig plads både i felten og i litteraturen om det nordlige Uganda. Begge begreber fører en række praksisser med sig, som udleves og evalueres, og begge kan siges at producere 'looping effekter' (Hacking, 1995), fordi det at give navn til fænomener og bygge institutioner og behandlingspraksisser op også er med til at konstituere problemerne.

Begge begreber spredes som diagnostiske kategorier og indgår i konfigurationer med erfaringer, aktører, institutioner, praksisser og genstande. I de følgende afsnit behandler vi begreberne, viser hvilke institutioner, der promoverer begreberne, og hvordan de bliver relevante kategorier for folk i Acholi-regionen og således indgår i større konfigurationer.

\section{Den dårlige død kontaminerer}

Cen er overvejende beskrevet i litteraturen som en åndelig kontaminering, man kan pådrage sig ved omgang med 'dårlig død'. Ved for eksempel at begå mord, ved at befinde sig i områder, hvor mord er begået, eller ved at behandle døde kroppe på 
uværdige måder kan man pådrage sig en besættelse eller åndelig kontaminering (Meinert \& Whyte, 2016a; 2016b). Den bredere litteratur fra regionen påpeger den åndelige kontaminering som i højere grad personlig (Finnström, 2003; p'Bitek, 1971) eller mere upersonlig og kollektiv (Behrend, 1999), eller ved at understrege, at bruddet på en moralsk orden kræver bod (Evans-Pritchard, 1956). Begrebet cen med den samme generelle betydning er udbredt i det meste af Østafrika og kan findes på alle de nilotiske sprog (Evans-Pritchard, 1965, 173) og nogle bantu sprog (Whyte 1997, 132-40). Cen ånder er ofte kontrasteret til tipu, ånderne af de som døde en 'god død', eller kwaro, forfædrenes ånder. Begge bidrager til gode liv for deres efterkommere. De døde bliver til eller skaber cen, når der har foregået et moralsk brud, og den sociale anerkendelse af cen er således også en anerkendelse af, at nogen har gjort noget moralsk forkasteligt, som kræver oprettelse.

Symptomerne på cen dækker en bred pallet af adfærd og oplevelser. Mareridt og syner, som ofte involverer døde, der enten kommer efter én eller anklager én moralsk, vandren rundt uden grund, ukontrollable følelsesudbrud på upassende tidspunkter, afvisning af huslige pligter, aggressiv og psykoselignende adfærd vil ofte være en del af beskrivesen af cen.

Transmissionsvejen for cen er som nævnt ofte i forbindelse med en 'dårlig død', ved at slå ihjel, befinde sig hvor mord er blevet begået, have omgang med døde, som er afgået ved umoralske handlinger - dette gælder også over generationer, hvor cen kan spredes eller smitte ned igennem en slægt, fordi tidligere familiemedlemmer var involveret i umoralske handlinger. Cen er således ikke nødvendigvis personlig og udtryk for, at den enkelte har gjort noget forkert. Der kan være tale om umoralske handlinger begået langt tilbage i historien og slægten. Nogle mener, at Cen også kan smitte ved fysisk kontakt med den problematiske effekt, at folk, som opleves at have cen, ofte bliver udstødt. Dette gælder i særlig grad folk, som er blevet taget af rebelgrupperne, eller selv har tilsluttet sig og kæmpet i bushen. Når de vender hjem, mistænkes de ofte for at bringe cen med sig og bliver stigmatiserede i lokalsamfundet.

Man kan som nævnt også pådrage sig cen ved at opholde sig i bestemte områder, hvor folk har lidt en 'dårlig død' og ikke er blevet begravet på ordentlig vis. Det er måske det klareste eksempel på cen som kontaminering og ikke som smitte, da smittevejen her ikke er en person, men et område. Handlingsmulighederne i disse tilfælde kan også være rettet mod områder og ikke kun personer. Renselsesritualet moyo piny, en renselses af omgivelser, er et sådant ritual, som kan modstilles moyo kum, der er renselse af kroppen. Sverker Finnström beskriver i sin monografi (2003) fra Acholi under krigen, hvordan indbyggerne oplever, at 
regionen gennemgår historiske perioder med mere eller mindre forurenede omgivelser. Finnström (2003) bruger ikke kontamineringsbegrebet, men det lokale begreb for dårlige omgivelser (piny marac), men argumentet i etnografien er på mange måder det samme.

Tager vi disse lokale begreber og forståelser i betragtning, er det forståeligt, at et område som Acholi-regionen, der har været hærget af krige og militære konflikter siden 1980'erne, har skabt grobund for udbredelse af cen. Men cen og måder at håndtere dette på forandrer sig også ved at indgå i nye konfigurationer over tid. Heike Behrend (1999) beskriver i sin etnografi fra regionen, hvordan soldater, som havde kæmpet mod regeringstropperne andre steder i Uganda, var forurenet med cen efter de mange drab og bragte det med hjem, da de vendte tilbage. Behrends pointerer, at det ikke var drabene i sig selv, som var det problematiske, men mere dét at soldaterne ved deres hjemkomst ikke blev renset rituelt for cen af de ældre, som det tidligere havde været praksis at gøre efter krig. Her var altså en historisk forandret konfiguration, som gjorde, at cen ikke blev taget hånd om og derved fik lov at forurene Acholiland.

Men ikke kun menneskelige aktører, såsom de klanældste, påvirker konfigurationer og kontaminering. Også udviklinger i materialer og teknologier bidrager til forandringer i konfigurationer. Tidligere hvor drab og krige udkæmpedes med spyd, kunne partnerne tydeligt se hinanden, og man vidste således, hvor ansvaret for drabet lå (Hutchinson, 1996, 107). Men med nye krigsformer og ny våbenteknologi kommer nye konfigurationer af kontaminering, og nye smitteveje åbnes op. Moderne våbenteknologi, så som maskingeværer, landminer og granater, genererer mange lig, som ikke bliver begravet korrekt (fordi der er for mange lig i forhold til begravelsesressourcer, og fordi reglerne for krig ændrer sig). Våbenteknologien kan derudover bruges på så stor afstand, at det er vanskeligt at vide, hvem der har dræbt hvem. Herved opstår åndelig kontaminering på nye måder, og nye ritualer må opfindes til at håndtere disse. I Acholiland findes adskillige eksempler på ritualer, som er blevet forandret og tilpasset disse nye forhold. Renselsesritualet, 'at træde på ægget' (nyono tonggweno), blev tidligere brugt, når medlemmer af klanen havde været væk i længere tid og måske havde pådraget sig cen eller andre former for kontaminering. Mest kendt i litteraturen er mato oput ritualet ('at drikke den bitre urt'), som historisk var et forsoningsritual mellem to klaner, når et mord var blevet begået (Finnegan, 2010). Begge disse ritualer er blevet omskabt i moderne tid for at tilpasses nye krigsformer. Ritualerne, som før foregik mellem klaner i langt mindre skala, er blevet afprøvet som store kollektive ritualer brugt til reintegration af tidligere rebelsoldater og ofte sponsoreret af udenlandske NGO'er 
(Harlacher et al., 2006; Allen, 2008). Udenlandske aktører har eksempelvis sørget for, at flere traditionelt separate ritualer for eksempel mato oput og gomo tong ('at bøje spyd) blev kombineret til ét nyt ritual, fordi det skulle virke fremmende på freden i området. Dette blev sponsoreret med ressourcer fra blandt andet NGO'en ACORD og den Belgiske regering (Allen, 2008).

\section{Cen: Institutioner, kontaminering og sociale smitteveje}

De institutioner, som er med til at behandle og rense for cen, er samtidig med til at opretholde forestillinger om cen. Mindst tre institutioner er med til at behandle og opretholde disse forestillinger og praksisser, hvoraf den mest centrale er ajwaki, de traditionelle behandlere. Ajwaki diagnosticerer deres klienter ud fra forestillinger om cen som beskrevet ovenfor, og de arrangerer og orkestrerer behandlingsritualer og ofringer. Flere informanter peger på, at antallet af ajwaki er steget markant efter de mange år med krig. Denne stigning går hånd i hånd med den åndelige kontaminering, således at lidelse og behandlingsinstitutioner opretholder hinandens eksistens og relevans. Samtidig er ajwaki arbejdet også en kærkommen måde at indtjene sit levebrød for mange efter krigen. De kristne kirker spiller også en markant rolle i behandling af cen. Deres begrebsliggørelser af cen varierer fra de traditionelle behandleres, og deres referencepunkter til onde ånder i Bibelen er anderledes, men mange af de grundlæggende forestillinger er stadig de samme, for eksempel at åndelig kontaminering kan vandre ned igennem generationer. Behandlingsmetoderne er dog anderledes end de traditionelle behandleres med et stærkt fokus på bøn og personlig tro og ofte i kombination med biomedicinering. Der forefindes et udtalt konkurrenceforhold mellem ajwaki og kirker i forhold til, hvem der har ret til at behandle og med hvilke metoder, netop fordi det er mange af de samme lidelser, de behandler. Den tredje gruppe af institutioner, som fylder på behandlingsmarkedet, er NGO'erne og organisationen Ker Kwaro Acholi, som er sammenslutningen af traditionelle ledere. I områder hvor folk lider af forskellige former for cen, kan både de traditionelle ledere og NGO'erne sætte ind med kollektive renselsesritualer af både personer og steder, og ofte vil NGO'erne sponsorere udgifter for Ker Kwaro Acholi. Det kan for eksempel være i forbindelse med udgifterne til transport af offerdyr til renselsesritualer. På denne måde overlapper de forskellige institutioner med hinanden både i forhold til behandlingsmetoder, lidelsesforestillinger og økonomi. De er ikke parallelt fungerende institutioner og aktører, men indgår løbende i konfigurationer med hinanden. Et samarbejde kan 
vare en periode eller i forbindelse med et specifikt ritual, og herefter sammensættes nye konfigurationer af samarbejder og behandlingsveje.

\section{Traume-imperium?}

Forestillinger om traumer har efter Vietnamkrigen spredt sig fra det Globale Nord til resten af verdens brændpunkter med en hastighed, som har fået eksperter til at anvende begrebet 'traume imperium' (Fassin \& Rechtman, 2007). Traumebegrebet er også nået til det nordlige Uganda i flere versioner. Én er den stringente, monolitiske kategori Post Traumatisk Stress Disorder (PTSD) baseret på kriterier fra DSM-diagnostikken fra American Psychological Association (Young 1995, 118). PTSD er en diagnose, som stilles ud fra en række symptomer sat i forhold til en viden om episoder i klientens liv, hvor vedkommende har været eksponeret for ekstremt stressende situationer. Diagnosen peger frem mod behandling med psykoterapi og/eller psykofarmaka. Det engelske ord trauma er blevet et almindeligt begreb brugt i Acholi som en bredere betegnelse for en variation af mentale, emotionelle og adfærdsmæssige konsekvenser af oplevelser af vold, som peger mod forskellige former for behandling og omsorg. Blandt dem med lidt højere uddannelse bliver det også flittigt brugt om tristhed og depressiv adfærd efter tab eller oprivende oplevelser. Fra tid til anden kan man også høre trauma blive brugt $\mathrm{i}$ daglig tale om alt fra Downs Syndrom til voldsomme nederlag i sportsverdenen. Trauma bliver dog ikke brugt til at betegne kropslige sår og kvæstelser (som i biomedicinen), men refererer udelukkende til mentale problemer eller tilstande.

Traumebegrebets historiske indtog i Uganda var primært igennem 1990'ernes HIV/AIDS-programmer. En nøgleinformant fortalte, at første gang, han hørte om 'trauma', var, da han arbejdede sammen med udenlandske NGO'er i forbindelse med diagnosticering og behandling af HIV-smittede. Her hed det sig, at meldingen om en positiv HIV-test kunne give folk chok og traumer, der kaldte på samtaleterapeutiske greb, som han og andre frivillige blev oplært i. Således kom begrebet 'counseling' også ind i acholi-sprog og praksis i samklang med traumebegrebet som andre steder i Uganda (Whyte, et al., 2013) og Østafrika (Prince, 2014). Herved blev specifikke euro-amerikanske forestillinger som et psykologisk og terapeutisk selv (Rose, 1998) også promoveret og udbredt i Uganda. Infrastrukturen omkring HIV/AIDS-behandling gødede på denne måde jorden for særlige forestillinger om selvet og psyken som en entitet, der kan blive traumatiseret og behandlet psykoterapeutisk. 
Særligt for det nordlige Uganda var etableringen af receptionscentre i 1990'erne og 00'erne til at modtage hjemvendte børnesoldater og andre, som blev bortført af rebelgrupperne, centrale for spredningen af traumebegrebet. Et stort antal børn og unge $^{2}$ blev sluset igennem disse receptionscentre over de sidste 20 år, hvor der har været et stort fokus på traumer og samtaleterapi (Verma 2012). Flere receptionscentre havde samarbejde med psykoterapeutiske NGO'er, hvortil centrene kunne henvise folk, som, de vurderede, ville have godt af yderligere psykoterapi. En undersøgelse fra 2005 fandt, at det mest værdsatte element i receptionscentrene var samtaleterapien, men studiet kritiserede samtidig disse praksisser for, at der ikke var nogen vurdering af, hvorvidt eller hvordan det hjalp de tilbagevendte (Allen \& Schomerus, 2006).

Som nævnt har et væld af NGO'er med mere eller mindre specifikt fokus på både traume-behandling og -forskning arbejdet i det nordlige Uganda både under og efter krigen. Et studie fra 2006 fandt en af de højest målte koncentrationer af depression og PTSD i konfliktområder i Gulu- og Amuru-distrikter (Roberts et al., 2008). Studierne beretter, at $67 \%$ af befolkningen i de nævnte distrikter mødte kriterier for depression og 54\% for PTSD målet med Hopkins Symptom Checklist-25 og Harvard Trauma Questionnaire (Kleijn et al., 2001). Et andet studie identificerede, at der i 2012 stadig var 25 NGO'er i Acholi-regionen, som arbejdede direkte med traumebehandling (Whyte et al., in press). Her kunne nævnes mange, men nogle af de mest fremtrædende i landskabet er Transcultural Psychosocial Organisation (TPO), som laver 'outreach' programmer i en række mindre landsbyer igennem samarbejde med lokale sundhedscentre. I den lille afsidesliggende landsby Paibona i Gulu-distriktet kommer TPO forbi en gang månedligt og diagnosticerer. På den måde leverer TPO også lidelsesforklaringer og -begreber, ofte traume/ PTSD diagnoser, som indgår i konfigurationer med lokale forestillinger. Et andet eksempel er den tysk-italienske organisation Vivo, som både laver traumeterapi baseret på Narrativ Eksponerings Teori og samtidig forsker i traumeudbredelse og behandling (se f.eks. Neuner et al., 2008; 2012 og Ertl et al., 2010). Vivo har etableret et samarbejde med den tidligere nævnte organisation af traditionelle ledere Ker Kwaro Acholi, hvorigennem de finder deres klienter og forskningssubjekter. Vivo har screenet og behandlet langt over tusinde klienter i Acholi-regionen. Som en fast del af Vivos traumeterapi indgår også psykoeducation, det vil sige undervisning til klienterne $i$, hvordan psyken fungerer, og hvad traumer er, inden behandlingen starter. Psykoeducation er måske et af de mest konkrete eksempler på, hvordan forestillinger om psyken og psykiske lidelser transmitteres socialt. 
Både sygeplejesker fra hospitalet og lokalt uddannede terapeuter fra Vivo fortæller, at der ikke findes nogen direkte oversættelse af ordet 'traume' på acholi. Nogle sygeplejesker bruger ajiji, som henviser til en intens frygt i forbindelse med mareridt og syner - nogle gange aggression eller distraktion. Ajiji kan dog også henvise til sorg efter et tab, afhængigt af hvordan det bruges. De lokalt uddannede Vivo terapeuter fortæller, at de beskriver symptomerne på PTSD og hører om deres klienter, hvorved de kan genkende det. De fortæller, at de ikke afviser deres klienters forestillinger om ånder eller djævlen, men opfordrer dem til at se, om samtaleterapien virker.

På mange måder ser det nordlige Uganda ud til at være blevet en del af det globale 'traume imperium' beskrevet af Fassin og Rechtman (2007), som blandt andet også peger på, hvordan det er et forholdsvist nyt historisk fænomen, at det ikke kun er ofret, men også gerningsmanden i en konflikt situation, der ses som skadet og traumatiseret ${ }^{3}$. Denne betragtning er måske særlig relevant et sted som Uganda, hvor et stort antal børn og helt unge blev bortført og gjort til soldater. Igennem receptionscentrene lærte disse bortførte da også at fortælle deres historier på måder, som passede ind i fortællingen om det sårbare barn, som blev gjort til soldat mod sin vilje, og som derfor ikke bør bære ansvaret for sine handlinger (Akelle et al. 2006; Verma, 2012).

Flere kritiske røster inden for forskningsverdenen har også peget på det generelle skred, som er sket i begrebsliggørelsen af humanitært arbejde fra et fokus på mad og sikkerhed til psykologi og traumebehandling af ofre (Enomoto, 2011; 2014; Bracken, 1998). Flere kritikere peger på, hvordan dette reflekterer en neoliberal orientering i det Globale Nord, hvor sociale problemer bliver gjort til individuelle, psykologiske problemer (Pupavac, 2004; 2006). Nogle kalder endog dette for en form for 'therapeutic governance' af udviklingslande (ibid.; Enomoto, 2011).

\section{Pragmatisme og sameksistensen af cen og traumer}

Forholdet mellem forestillinger om cen og traumer er komplekst. Et oplagt argument for at forholde sig parallelt til disse lidelsesforestillinger er, at de forskellige symptomer synes at overlappe. Alfreds symptomer med pludselige aggressive udbrud, mareridt, hukommelsessvigt og syner, som kan forbindes til fortidig vold, vil kunne leve op til diagnosekriterier for både cen og traume.

I forskellige sammenhænge eksisterer de varierende forestillinger også i sammensmeltede og synkretistiske transformationer. Flere sundhedsarbejdere på 
psykiske sygeafdelinger i Gulu og Lira distrikter beskrev forholdet mellem cen og traumer, som at 'ånderne kan give én PTSD'. Denne synkretisme peger, ifølge sundhedsarbejderne, behandlingsmæssigt frem mod samtaleterapi og biomedicinering som midlertidig symptombehandling, åndemaning og renselsesritualer som oprettende og kompensatorisk behandling samt eventuelt bønner og kirkefællesskab som supplerende elementer. Nogle sundhedsarbejdere afviser dog al snak om ånder og sætter udelukkende deres lid til DSM-systemets præcision og effekten af psykofarmaka. Særligt inden for de mange kirker findes versioner af disse synkretismer. 'Trauma persons', en betegnelse man særligt hører inden for kirkerne, kan have brug for en blanding af bøn, biomedicin og samtaleterapi for at overkomme deres problemer. Forskellige tilstande opleves som forårsaget af en blanding af mange ting og modsvares derfor også bedste af behandling, som er en kombination af forskellige strategier.

Ressourcer og tid spiller en stor rolle i den måde, hvorpå folk sammensætter de forskellige behandlingstilbud. Renselsesritualer er ofte meget dyre, og der skal samles penge ind fra hele klanen. Det kan tage måneder eller år. Psykofarmaka er også dyrt, og ofte kan man ikke få det ideelle præparat i de rigtige doser, fordi sygehusene og apotekerne ikke har det på lager. Som i Alfreds tilfælde betyder økonomien, at mange, som har prøvet dyre renselsesritualer, eller som slet ikke har råd til dem i første omgang, søger mod kirkerne, hvis behandlingstilbud er langt billigere. Her er tid også en faktor. Hvor NGO'en Vivos traumeterapi som standard løber over 12 samtaler og derefter slutter, varer mange af kirkernes samtaletilbud og fællesskab potentielt resten af livet. David, én af vores centrale informanter, hvis far var alvorligt syg med symptomer, der mindede om Alfreds, sagde, at de i familien var meget uenige om, hvad problemet skyldtes. De havde prøvet med bønner og med anti-psykotisk- og depressionsmedicin fra hospitalet, og faren havde også været indlagt på Butabika Psykiatriske Hospital i hovedstaden Kampala. Familien var også ved at samle ind til et stort renselsesritual, og mens de ventede, prøvede de forskellige andre behandlingsveje. Faren havde en bipolar diagnose fra den psykiatriske afdeling, men denne diagnose afviste NGO'en TPO som invalid, hvorefter de ønskede at diagnosticere faren på ny og tilbyde ny biomedicin.

Disse forhold peger også på det potentielt problematiske ved at bruge eksempelvis cen og traumer som monolitiske og statiske kategorier til at forstå sygdoms- og behandlingsforløb. Mange vil, som Alfreds og Davids familier, være pragmatisk orienteret i forhold til lidelse og behandling, og mange sygdomsforløb og symptomer vil, som Alfreds, forandre sig afhængig af, hvilke konfigurationer de indgår 
i. Det virker således hensigtsmæssigt, at undersøge disse sygdomsforløb inden for de konfigurationer, de forekommer i, i den praksisnære og materielle kontekst i stedet for henvisning til traumer og ånder som statiske, bagvedliggende entiteter.

\section{Hinsides kausale, essentialistiske og social konstruktionistiske forklaringmodeller?}

Et fokus på konfigurationer som analytisk begreb bringer en epistemologisk rekonceptualisering af både cen og traumer med sig; Ikke som kosmologiske eller psykologiske entiteter, der findes derude og derinde, men som måder at spørge på og som en pragmatisk afprøvning, der forbliver åben for forandringer, uvished og nye forklaringer. Dette perspektiv medbringer et epistemologisk skift fra en korrespondens teori om viden, hvor begreber fungerer som et naturens spejl (Rorty, 1980), til en pragmatisk og uvishedens epistemologi, hvor begreber i højere grad er arbejdshypoteser (Brinkmann \& Tanggaard, 2010; Dewey 1990, Whyte 1997). Et fokus på konfigurationer må nødvendigvis bygge på en sådan pragmatisk epistemologi for at bibeholde den åbenhed for det systemiske, dynamiske og transformative, som netop er styrken ved dette perspektiv.

I stedet for at forstå lidelser som cen, djævlen og traumer som afgrænsede problemer, som individer bærer rundt i sig, så forstår vi disse lidelser som kontekstuelt og processuelt konfigurerede, der fremkommer i bestemte samspil. Det er veldokumenteret, at PTSD påvirker hjernen bio-kemisk og fysiologisk, men dette skal imidlertid ikke begrænse vores fokus. Enheder og sammenhænge, som er større end hjernen og individet, er ligeledes involverede og relevante at undersøge. Traumer og åndebesættelser kommer frem i særlige konfigurationer, hvor kroppen og hjernen, der også er porøse selver, spiller en stor rolle, men langtfra den eneste. Det er bestemte samspil, som får traumer og ånder til at fremtræde, og andre kan få dem til at forsvinde igen. Derved bliver konfigurationer (og ikke bare individer) den relevante enhed og fokus for vores analyse. Konfigurationen kan være familierelationers dynamikker med forskellige typer af behandlingssystemer, som overlapper over en periode som i historien om Alfred. Vi har ved hjælp af begrebet om konfigurationer forsøgt at udvikle en systemisk tilgang hvor det fænomenologiske og pragmatiske spiller en central rolle, og hvor den sociale konstruktion af diagnoser spiller en sekundær rolle. 
Den epistemologiske position, som ligger bag ideen om konfigurationer, er ikke ny. Den er formuleret mange steder af både pragmatikere som John Dewey (Bentley \& Dewey, 1949; Brinkmann, 2006), systemtænkere som Bateson (Bateson, 2006), i aktør-netværks teori (Latour, 2005), i positioneringsteori (Harré \& Langhoven, 1999; Williams et al, 2014) og findes også i store dele af Wittgensteins forfatterskab (1967; 1979). Alle disse tilgange kan siges at have et analytisk udgangspunkt, som fokuserer på processer, situationer og transformationer. Om end de kaldes begivenheder (Dewey), episoder (positioneringsteori) systemer eller netværk (aktør-netværks teori), holder de alle på et perspektiv, hvor processer er mere grundlæggende kategorier end objekter og afgrænsede entiteter. Det samme kan her siges om konfigurationer som analytisk begreb.

Som et komplementerede perspektiv til Fassin og Rechtmans (2007) begreb om et 'traume imperium' har vi forsøgt at vise, hvordan dette 'imperium' ser ud fra et nært og ruralt perspektiv i det nordlige Uganda. Herfra ser imperiet ikke så magtfuldt og veludrustet ud. Om ikke andet så er det én organiseringsform blandt andre. Det viser blandt andet udbredelsen af forestillinger om cen og djævlen som ophav til lidelse. Sameksistensen af cen, traumer og djævlen, de forskellige behandlingsveje, som disse forestillinger peger frem mod, de synkretistiske forhold, de ofte indgår i, samt den pragmatisme hvormed folk forholder sig til deres lidelser, viser, at kausale, psykologiske begreber om traumer og tilhørende behandlingsformer ikke er tilstrækkeligt til at møde de forhold, som folk i det rurale Uganda lever med. Dette viser historierne om Alfred, David og de andre, vi har fulgt, hvis lidelsesforløb fortsat bliver genfortalt og genforhandlet igennem nye samspil og udvekslinger.

\section{Noter}

${ }^{1}$ Det 'Globale Nord' inkluderer USA, Canada og Vesteuropa og udviklede dele af Asien, såvel som Australien og New Zealand, på trods af at disse ikke ligger i det geografiske nord, men til gengæld deler økonomiske og kulturelle karakteristika med førstnævnte lande.

${ }^{2}$ Det er vanskeligt at sige præcist hvor mange, som har været igennem receptionscentrene i Gulu. I følge Allen \& Schomerus (2006) har det varieret meget fra år til år med over 4000 personer i 2003 og ned til omkring 600 i 2005.

${ }^{3}$ Dette ligner Hackings pointe i forhold til børnemishandling, hvor det ikke kun er offeret, der italesættes som havende behov for behandling og terapi, men i høj grad også gerningsmanden (Hacking, 1992). 


\section{Referencer}

Ager, A. (1993). Mental health issues in refugee populations: A review. Cambridge, USA: Harvard Medical School, Department of Social Medicine.

http://repository.forcedmigration.org/show_metadata.jsp?pid=fmo:1082 Besøgt d. 25.04.2016.

Ager, A. (1997). Tensions in the psychological discourse: implications for the planning of interventions with war-affected populations. Development in Practice 7, 402-407. https:// doi.org/10.1080/09614529754198

Akello, G., Richters, A., \& Reis, R. (2006). Reintegration of former child soldiers in northern Uganda: Coming to terms with children's agency and accountability. Intervention, 4, 229-243. https://doi.org/10.1097/WTF.0b013e3280121c00

Allen, T. (2008). Ritual (Ab) use? Problems with Traditional Justice in Northern Uganda. In N. Waddell \& P. Clark (Eds.), Courting conflict? Justice, Peace and the ICC in Africa (pp.4754). London, UK: The Royal African Society.

Atkinson, R. (1994). The Roots of Ethnicity: The Origins of the Acholi of Uganda Before 1800. Philadelphia, USA: University of Pennsylvania Press.

Bateson, G. (2006). Mind and nature: A necessary unity (Advances in systems theory, complexity, and the human sciences). Auckland, New Zealand; EDS Publishing Ltd.

Behrend, H. (1999). Alice Lakwena and the Holy Spirits: war in northern Uganda, 1985-97. Athens, USA: Ohio University Press.

Bracken, P. J., \& Petty, C. (Eds.). (1998). Rethinking the trauma of war. London, UK: Free Association Books.

Brewin, CR (2001). A cognitive neuroscience account of posttraumatic stress disorder and its treatment. Behaviour Research \& Therapy 39 (4), 373-381. Doi: 10.1016/S00057967(00)00087-5

Brinkmann, S. (2006). John Dewey. En introduktion. København, DK: Hans Reitzel.

Brinkmann, S., \& Tanggaard, L. (2010). Toward an epistemology of the hand. Studies in philosophy and education, 29, 243-257. https://doi.org/10.1007/s11217-009-9164-0

Csordas, T. J. (1997). The sacred self: A cultural phenomenology of charismatic healing. Oakland, USA: University of California Press.

Dewey, J. (1990). Psychology and Social Practice. The Psychological Review, 7, 105-124. https:// doi.org/10.1037/h0066152

Dewey, J., \& Bentley, A. F. (1960). Knowing and the known. Boston, USA: Beacon Press.

Desjarlais, R. (1996). World mental health: Problems and priorities in low-income countries. Oxford University Press, USA.

Dolan, C. (2008). Social torture. The case of northern Uganda, 1986-2006. New York, USA: Berghahn Books

Ehlers, A., \& Clark, D. M. (2000). A cognitive model of posttraumatic stress disorder. Behaviour research and therapy, 38, 319-345. https://doi.org/10.1016/S0005-7967(99)00123-0

Enomoto, T. (2011). Revival of tradition in the era of global therapeutic governance: the case of ICC intervention in the situation in northern Uganda. African Study Monographs, 32, 111-134.doi:10.14989/147079

Ertl, V., Pfeiffer, A., Schauer, E., Elbert, T., \& Neuner, F. (2011). Community-implemented trauma therapy for former child soldiers in Northern Uganda: a randomized controlled trial. Jama, 306, 503-512. https://doi.org/10.1001/jama.2011.1060 
Evans-Pritchard, E. E. (1965). Theories of primitive religion. Oxford, UK: Clarendon Press.

Finnegan, A. C. (2010). Forging forgiveness: Collective efforts amidst war in Northern Uganda. Sociological Inquiry, 80, 424-447. https://doi.org/10.1111/j.1475-682X.2010.00341.x

Finnström, S. (2008). Living with bad surroundings: war, history, and everyday moments in northern Uganda. Durham, USA: Duke University Press. https://doi.org/10.1215/9780822388791

Good, B. J. (1993). Medicine, rationality and experience: an anthropological perspective. Cambridge University Press. https://doi.org/10.1017/cbo9780511811029

Gluckman, M. (2012). Politics, law and ritual in tribal society. AldineTransaction.

Hacking, I. (1992). The making and molding of child abuse. Critical inquiry, 17, 253-288. https://doi.org/10.1086/448583

Hacking, I. (1995). The looping effects of human kinds. In D. Sperber, D. Premack, D., \& A. J. Premack (Eds.), Causal cognition: A multidisciplinary debate (pp. 351-394). New York: Oxford University Press.

Harlacher, T. (2009). Traditional ways of coping with consequences of traumatic stress in Acholiland Northern Ugandan. Ethnography from a Western psychological perspective. PhD. Dissertation. University of Freiburg, Switzerland.

Harlacher, T., Okot, F. X., Obonyo, C. A., Balthazard, M., \& Atkinson, R. R. (2006). Traditional Ways of Coping in Acholi. Kampala, Uganda: Intersoft Buisness Services Ltd.

Harré, R., \& van Langenhoven, L. (1998). Positioning theory: Moral contexts of intentional action. Massachusetts, USA: Blackwell Publishing Ltd.

Hofmann, S. G., \& Smits, J. A. (2008). Cognitive-behavioral therapy for adult anxiety disorders: a meta-analysis of randomized placebo-controlled trials. The Journal of clinical psychiatry, 69, 199-210.

doi: 10.1016/j.cpr.2007.04.009

Hopwood, J. \& Osburn, C. (2008) Sharing the Burden of the Past: Peer Support and Self Help Amongst Former Lord's Resistance Army Youth. Gulu: The Justice and Reconciliation Project, Quaker Peace and Social Witness http://justiceandreconciliation.com/wp-content/ uploads/2008/05/JRP_Report_SharingtheBurden.pdf

Besøgt d. 27.02.2016

Hutchinson, S. E. (1996). Nuer dilemmas: coping with money, war, and the state. Oakland, UAS. University of California Press.

Kleijn, W. C., Hovens, J. E., \& Rodenburg, J. J. (2001). Posttraumatic stress symptoms in refugees: assessments with the Harvard Trauma Questionnaire and the Hopkins Symptom Checklist-25 in different languages. Psychological reports, 88, 527-532. https://doi. org/10.2466/pr0.2001.88.2.527

Latour, B. (2005). Reassembling the social: An introduction to actor-network-theory. Oxford, UK: Oxford University Press.

Martin, D. (2002). Pentecostalism: The world their parish. Oxford, UK: Oxford University Press.

Mattingly, C. (2014). Moral laboratories: Family peril and the struggle for a good life. University of California Press. https://doi.org/10.1525/california/9780520281196.001.0001

Maxwell, D. (2006). African gifts of the spirit: Pentecostalism \& the rise of a Zimbabwean transnational religious movement. Melton, UK: James Currey Publishers.

Meinert, Lotte (2009) Hopes in Friction: Schooling, Health and Everyday Life in Uganda. Charlotte NC: Information Age Publishing. 2009.

Meinert, L. \& Whyte, S. R., (2016 under review) Legacies of Violence: The Communicability of Spirits and Trauma in Northern Uganda. In J. Seeberg, A. Roepstorff \& L. Meinert 
(Eds.), Beyond Biodeterminism : Anthropological Encounters with Bio-collaboratives Durham, USA: Duke University Press.

Meinert, L., \& Whyte, S. R. (2016 under review). These Things Continue. Violence as contamination in everyday life after war in Northern Uganda. Ethos.

Meinert, L., Obika, J. A., \& Whyte, S. R. (2014). Crafting forgiveness accounts after war: Editing for effect in northern Uganda. Anthropology Today, 30, 10-14. https://doi. org/10.1111/1467-8322.12120

Meyer, B. (1999). Translating the Devil: religion and modernity among the Ewe in Ghana. Edinburgh, Scotland: Edinburgh University Press.

Mogensen, H. O. (2002). The resilience of juok: confronting suffering in Eastern Uganda. Africa, 72, 420-436. https://doi.org/10.3366/afr.2002.72.3.420

Neuner, F., Catani, C., Ruf, M., Schauer, E., Schauer, M., \& Elbert, T. (2008). Narrative exposure therapy for the treatment of traumatized children and adolescents (KidNET): from neurocognitive theory to field intervention. Child and adolescent psychiatric clinics of North America, 17, 641-664. https://doi.org/10.1016/j.chc.2008.03.001

Neuner, F., Onyut, P. L., Ertl, V., Odenwald, M., Schauer, E., \& Elbert, T. (2008). Treatment of posttraumatic stress disorder by trained lay counselors in an African refugee settlement: a randomized controlled trial. Journal of consulting and clinical psychology, 76, 686-694. doi: 10.1037/0022-006X.76.4.686

Neuner, F., Pfeiffer, A., Schauer-Kaiser, E., Odenwald, M., Elbert, T., \& Ertl, V. (2012). Haunted by ghosts: Prevalence, predictors and outcomes of spirit possession experiences among former child soldiers and war-affected civilians in Northern Uganda. Social Science $\mathcal{E}$ Medicine, 75, 548-554. https://doi.org/10.1016/j.socscimed.2012.03.028

p'Bitek, O. (1971). Religion of the Central Luo. Nairobi, Kenya: Kenya Literature Bureau.

Prince, R. J. (2014). Precarious projects: conversions of (biomedical) knowledge in an East African city. Medical anthropology, 33, 68-83. https://doi.org/10.1080/01459740.2013.833918

Pupavac, V. (2004). Psychosocial interventions and the demoralization of humanitarianism. Journal of Biosocial Science, 36, 491-504.

Pupavac, V. (2006) Humanitarian Politics and Disaster Psychology. In G. Reyes \& G. A. Jacobs (Eds.) Handbook of International Disaster Psychology. (pp. 15-34). London, UK: Praeger. https://doi.org/10.1017/S0021932004006613

Roberts, B., Ocaka, K. F., Browne, J., Oyok, T., \& Sondorp, E. (2008). Factors associated with post-traumatic stress disorder and depression amongst internally displaced persons in northern Uganda. BMC psychiatry, 8,1-9. doi: 10.1186/1471-244X-8-38

Rorty, R. (1980). Philosophy and the Mirror of Nature. Princeton, USA: Princeton University Press.

Rose, N. (1998). Inventing our selves: Psychology, power, and personhood. Cambridge, UK: Cambridge University Press.

Rosenberg, C. E. (1992). Explaining epidemics and other studies in the history of medicine. New York, USA: Cambridge University Press. https://doi.org/10.1017/CBO9780511666865

Schomerus, M. \& Allen, T. (2006) A hard homecoming: lessons learned from the reception center process in northern Uganda: An independent study. United States Agency for International Development / United Nations Children's Fund, Washington, USA.

http://eprints.1se.ac.uk/28888/1/__lse.ac.uk_storage_LIBRARY_Secondary_libfile_ shared_repository_Content_Schomerus,\%20M_Hard\%20homecoming_Schomerus_ Hard\%20homecoming_2014.pdf 
Besøgt d. 25.06.2016

Seeberg, J., \& Meinert, L. (2015). Can epidemics be noncommunicable? Reflections on the spread of 'noncommunicable'diseases. Medical Anthropological Theory 2, 54-71.

Singh, I., \& Rose, N. (2009). Biomarkers in psychiatry. Nature, 460, 202-207. https://doi. org/10.1038/460202a

Southwick, S., Rasmusson, A., Barron, J., \& Arnsten, A. (2005). Neurobiological and neurocognitive alterations in PTSD. Neuropsychology of PTSD: Biological, cognitive, and clinical perspectives, $727-58$.

Sriram, K., Rodriguez-Fernandez, M., \& Doyle III, F. J. (2012). Modeling cortisol dynamics in the neuro-endocrine axis distinguishes normal, depression, and post-traumatic stress disorder (PTSD) in humans. PLoS Computational Biology, 8, e1002379. https://doi. org/10.1371/journal.pcbi.1002379

Shostak, M. (2014). Nisa: The life and words of a Kung woman. Routledge.

Suedfeld, P. (ed.) (1990). Psychology and Torture: Clinical and Community Psychology. New York, USA, Hemisphere Publishing Corporation.

Verma, C. L. (2012). Truths out of place: homecoming, intervention, and story-making in war-torn northern Uganda. Children's geographies, 10, 441-455. https://doi.org/10.1080/14 733285.2012 .726075

Whyte, S. R. (1997). Questioning misfortune: the pragmatics of uncertainty in eastern Uganda. Cambridge, USA: Cambridge University Press.

Whyte, S. R., Whyte, M. A., Meinert, L., \& Twebaze, J. (2013). Therapeutic clientship: Belonging in Uganda's projectified landscape of AIDS care. In J. Biehl \& A. Petryna (Eds.), When people come first: Critical studies in global health (pp. 140-165). Princeton, USA: Princeton University Press. https://doi.org/10.1515/9781400846801-008

Williams, L. P. H., Christensen, M. K., Rytter, C., \& Musaeus, P. (2014). Clinical Positioning Space: Analyzing Doctor-Patient Relationships in the Outpatient Oncological Clinic. Qualitative Health Research. 25, 1049-7323.

Wittgenstein, L. (1967). Conversations on Aesthetics, Psychology and Religious Belief. Berkeley: University of California Press.

Wittgenstein, L., \& Rhees, R. (1979). Remarks on Frazer's Golden bough. London: Brynmill Press Ltd.

Young, A. (1997). The harmony of illusions: Inventing post-traumatic stress disorder. Princeton, USA: Princeton University Press. https://doi.org/10.1515/9781400821938 